\title{
Oxaliplatin Analogues with Carboxy Derivatives of Boldine with Enhanced Antioxidant Activity
}

\author{
Marco Mellado, ${ }^{1}$ Carlos Jara, ${ }^{2}$ David Astudillo, ${ }^{3}$ Joan Villena, ${ }^{3}$ \\ Patricio G. Reveco, ${ }^{1}$ and Franz A. Thomet ${ }^{1}$ \\ ${ }^{1}$ Departamento de Química, Universidad Técnica Federico Santa María, Avenida España 1680, 2390123 Valparaíso, Chile \\ ${ }^{2}$ Centro de Investigaciones Biomédicas (CIB), Escuela de Medicina, Universidad de Valparaiso, \\ Avenida Hontaneda 2664, 2340000 Valparaíso, Chile \\ ${ }^{3}$ Laboratorio de Investigación-Estrés Oxidativo, Escuela de Medicina, Universidad de Valparaiso, \\ Avenida Brasil 1560, 2340000 Valparaíso, Chile
}

Correspondence should be addressed to Franz A. Thomet; franz.thomet@usm.cl

Received 3 December 2014; Revised 22 January 2015; Accepted 9 February 2015

Academic Editor: Viktor Brabec

Copyright ( $\odot 2015$ Marco Mellado et al. This is an open access article distributed under the Creative Commons Attribution License, which permits unrestricted use, distribution, and reproduction in any medium, provided the original work is properly cited.

A new oxaliplatin analog [Pt(dach)(L5)] (1) was synthesized and characterized as a continuation of a study of the previously reported $[\mathrm{Pt}(\mathrm{dach})(\mathrm{L} 6)](2)$, where dach $=(1 R, 2 R)$-diaminocyclohexane, $\mathrm{L} 5=3$-carboxyboldine, and L6 $=3$-carboxypredicentrine . Compounds 1 and $\mathbf{2}$ exhibited a substantially enhanced antioxidant activity compared to oxaliplatin (130 and 30 times for $\mathbf{1}$ and 13 and 4 times for $\mathbf{2}$ using the DPPH and FRAP assays, resp.). In addition, $\mathbf{1}$ and $\mathbf{2}$ exhibited cytotoxic activity in the same range as oxaliplatin toward the two human tumor cell lines (MCF-7 and HT-29) studied and two to four times lower activity in the human colon nontumor cell line (CCD-841). Preadministration of L5 or L6 to the colon tumor (HT-29) and the colon nontumor (CCD841) cell lines prior to oxaliplatin addition increased the viability of the nontumor cell line to a greater extent than that of the tumor cell line.

\section{Introduction}

The discovery of the biological properties of cisplatin has been the most relevant event in metal-based chemotherapeutics to date. The worldwide use of cisplatin over the last 35 years for different types of cancer (i.e., testicular, ovarian, and bladder cancer) has been limited due to its deleterious side effects, such nephro-, hepato-, cardio, and ototoxicity, as well as its chemical resistance [1]. The development of second and third generation drugs (i.e., carboplatin and oxaliplatin, resp.) has partially reduced these drawbacks. However, myelosuppression for carboplatin and neurotoxicity for oxaliplatin remain the primary secondary toxicities [2]. To decrease these undesired effects and/or to circumvent the cisplatin resistance, different strategies have been developed to design of new compounds [3]. Promising developments include the synthesis of picoplatin, which is a sterically hindered 2-methylpyridine platinum(II) compound with reduced reactivity in sulfur ligand reactions
[4], and satraplatin, which is a platinum(IV) compound that releases an active platinum(II) metabolite after intracellular reduction [5]. Biologically relevant molecules, such as estrogenic steroids, folic acid, sugar derivatives, antitumor natural products, and platinum-resistance modulators, have been coordinated to $\mathrm{Pt}(\mathrm{II})$ and $\mathrm{Pt}(\mathrm{IV})$ moieties to target tumor tissues [6-10]. The design of an improved drug delivery system is another field of chemotherapeutics that aims to provide treatment with fewer undesired effects. Liposomes, dendrimers, and carbon nanotubes have received increased attention in the last few years due to their potential for improving drug efficacy and reducing undesired secondary toxicities [11].

In recent years, increasing evidence suggests that a combination therapy involving natural chemopreventive agents and platinum-based drugs can enhance the effectiveness of the treatment [12] or reduce some of the metal induced secondary toxicities [13]. Quercetin, resveratrol, anethole, and curcumin have exhibited a synergic effect in combination 
with cisplatin and oxaliplatin in an in vitro model [14-16]. However, curcumin and capsaicin have exhibited a protective effect against cisplatin induced nephro- and neurotoxicity $[17,18]$.

To explore the potential pharmacological synergism between metal-based drugs and natural products, our research group has focused on the synthesis of these types of compounds employing natural derivatives as ligands $[19,20]$. Boldine (L1) is the main constituent of the endemic Chilean boldo tree (Peumus boldus Molina, Monimiaceae) and possesses important health-promoting properties, such as antioxidant, anti-inflammatory, and cytoprotective effects [21]. The use of boldine in a pretreatment regime decreased the cisplatin-induced lipoperoxidation in mice liver [22]. [Pt(dach)(L6)] (2; where dach $=(1 R, 2 R)$ diaminocyclohexane and L6 = 3-carboxypredicentrine) exhibited comparable cytotoxic activity toward three human tumor cell lines and a tenfold smaller biological activity in a nontumor cell line than the commercial drug oxaliplatin [19]. Herein, we described the synthesis of 3-carboxyboldine (L5) and the corresponding platinum(II) compound [Pt(dach)(L5)] (1). The antioxidant activity of L5 and L6 (as chlorohydrate salts) and metal complexes 1 and 2 was evaluated based on two chemical-based models (DPPH and FRAP assays), and the in vitro cytotoxic activity was evaluated for two human tumor cell lines (MCF-7 and HT-29) and one nontumor cell line (CCD-841). Also, to evaluate the potential cytoprotecting effect of the carboxy derivatives, especially on a nontumor cell line, pretreatment experiments using L5 or L6 (as chlorohydrate salts) with oxaliplatin on a human colon tumor cell line (HT-29) and a human nontumor cell line (CCD-841) were performed.

\section{Materials and Methods}

2.1. General Considerations. The NMR experiments were performed using an Avance 400 Digital Bruker NMR spectrometer operating at $400.13 \mathrm{MHz}$ for ${ }^{1} \mathrm{H}$ and at $100.61 \mathrm{MHz}$ for ${ }^{13} \mathrm{C}$. The chemical shifts $(\delta)$ are given in $\mathrm{ppm}$, and the coupling constant $(\mathrm{J})$ is reported in $\mathrm{Hz}$. The ${ }^{1} \mathrm{H}$ NMR chemical shifts are reported relative to the proton signal of incompletely deuterated DMSO- $\mathrm{d}_{6}\left(\begin{array}{l}\delta \\ 2.49\end{array}\right)$, and the ${ }^{13} \mathrm{C}$ NMR chemical shifts are relative to the carbon of DMSO- $\mathrm{d}_{6}$ $(\delta 39.5)$. The peak assignments were further confirmed by $2 \mathrm{D}-$ HSQC/HMBC experiments. The mass spectra were recorded on an ESI-IT Esquire 4000 Bruker spectrometer by direct injection using the Esquire Control 5.2 software. The infrared spectra were recorded on a FTIR Nicolet 4600 instrument, and the elemental analyses were performed on a Flash EA 1112.

Boldine (L1) was donated by INDENA. $\mathrm{K}_{2} \mathrm{PtCl}_{4}$, dach, $\mathrm{KI}$, $\mathrm{Ag}_{2} \mathrm{SO}_{4}, \mathrm{AgNO}_{3}$, and $\mathrm{Ba}(\mathrm{OH})_{2} \times \mathrm{H}_{2} \mathrm{O}$ were purchased from Aldrich. 2,9-Dimethoxymethyl-3-bromoboldine (L3) was prepared according to a previously published protocol with some modifications [23]. Chloromethyl methyl ether was synthesized using the method reported by Marvel and Porter [24], and the $\mathrm{Pt}$ complex $\left[\mathrm{Pt}(\mathrm{dach}) \mathrm{I}_{2}\right]$ was prepared from $\mathrm{K}_{2} \mathrm{PtCl}_{4}$ according to the procedure reported by Khokhar et al. [25]. 3-Carboxypredicentrine. $\mathrm{HCl}$ (L6) and boldiplatin (2) were prepared according to a previously published protocol [19]. The anhydrous solvents (i.e., acetone $\left(\mathrm{K}_{2} \mathrm{CO}_{3}\right)$, pyridine (4A molecular sieves), and THF ( $\mathrm{Na}$ /benzophenone)) were dried and freshly distilled. All of the other reagents were obtained from commercial suppliers and used without further purification.

2.2. Synthesis of 3-Carboxyboldine $(\mathrm{L} 5 \cdot \mathrm{HCl})$. To a solution of $1.15 \mathrm{~g}$ of 2,9-dimethoxymethyl-3-bromoboldine $(2.3 \mathrm{mmol})$ in $40 \mathrm{~mL}$ of dry $\mathrm{THF}$ at $-78^{\circ} \mathrm{C}, 3.0 \mathrm{~mL}$ of $\mathrm{n}$-BuLi $1.6 \mathrm{M}$ in hexane $(4.8 \mathrm{mmol})$ was added dropwise. After 1 minute, the cooling bath was removed, and $\mathrm{CO}_{2}$ gas was introduced into the solution for 10 minutes. The mixture was stirred for 2 hours at room temperature. The solvent was removed under reduced pressure, and the solid was dissolved in an acid mixture $(12 \mathrm{~mL}$ isopropanol, $12 \mathrm{~mL}$ THF, and $5 \mathrm{~mL}$ concentrated $\mathrm{HCl}$ ). The solution was stirred overnight at room temperature. The acid medium was removed under reduced pressure, and the residue was purified by column chromatography $(0.040-0.063 \mathrm{~mm})$ employing an increasingly polar mixture of $\mathrm{CHCl}_{3}: \mathrm{MeOH}=9: 1 \rightarrow 1: 1$ as the eluent. Yield: $0.461 \mathrm{~g}(1.1 \mathrm{mmol}, 48 \%)$ white solid. m.p. > $170^{\circ} \mathrm{C}(\mathrm{dec}) .{ }^{1} \mathrm{H}$ NMR $\left(400 \mathrm{MHz}, \mathrm{DMSO}_{6}, 25^{\circ} \mathrm{C}\right) \delta 2.40$ $(1 \mathrm{H}, \mathrm{dd}, \mathrm{J}=13.4$ and $13.6 \mathrm{~Hz}, \mathrm{H}-7), 2.64\left(3 \mathrm{H}, \mathrm{s}, \mathrm{N}-\mathrm{CH}_{3}\right), 3.02$ $(1 \mathrm{H}, \mathrm{d}, \mathrm{J}=12.6 \mathrm{~Hz}, \mathrm{H}-7), 3.1-3.3(2 \mathrm{H}, \mathrm{m}, \mathrm{H}-4+\mathrm{H}-5), 3.58$ $(1 \mathrm{H}, \mathrm{d}, 16.8 \mathrm{~Hz}, \mathrm{H}-4), 3.64\left(3 \mathrm{H}, \mathrm{s}, 1-\mathrm{OCH}_{3}\right), 3.77(3 \mathrm{H}, \mathrm{s}, 10-$ $\left.\mathrm{OCH}_{3}\right), 6.72(1 \mathrm{H}, \mathrm{s}, \mathrm{H}-8), 7.85(1 \mathrm{H}, \mathrm{s}, \mathrm{H}-11), 9.24(1 \mathrm{H}, \mathrm{s}, \mathrm{OH})$. ${ }^{13} \mathrm{C}$ NMR $\left(100 \mathrm{MHz}, \mathrm{DMSO}-\mathrm{d}_{6}, 25^{\circ} \mathrm{C}\right) \delta 27.4(\mathrm{C}-4), 32.4(\mathrm{C}-$ 7), $42.2\left(\mathrm{~N}-\mathrm{CH}_{3}\right), 52.4(\mathrm{C}-5), 55.7\left(10-\mathrm{OCH}_{3}\right), 58.5\left(1-\mathrm{OCH}_{3}\right)$, 62.5 (C-6a), 112.8 (C-11), 114.9 (C-8), 116.4 (C-3), 122.6 (C11a), 127.2, 128.8, 129.3, 143.3 (C-1), 146.0, 146.1 (C-10), 157.8, $172.0(\mathrm{COOH})$. IR (KBr disk) $3432 v(\mathrm{O}-\mathrm{H}), 2961,2934,1613$ $v\left(\mathrm{C}=\mathrm{O}\right.$ ), $1572,1510 \mathrm{~cm}^{-1}$. ESI-MS (positive mode) $\mathrm{m} / z 372$ $[\mathrm{MH}-\mathrm{Cl}]^{+}$. Anal. Calc. for $\mathrm{C}_{20} \mathrm{H}_{22} \mathrm{NO}_{6} \mathrm{Cl}$ : C, 58.90; H, 5.44; $\mathrm{N}, 3.43$. Found: C, 59.35; H, 5.60; N, 3.60.

2.3. Synthesis of [Pt(dach)(L5)] (1). A mixture of $0.340 \mathrm{~g}$ of $\left[\mathrm{Pt}(\mathrm{dach}) \mathrm{I}_{2}\right](0.60 \mathrm{mmol})$ and $0.206 \mathrm{~g}$ of $\mathrm{AgNO}_{3}(1.20 \mathrm{mmol})$ in $20 \mathrm{~mL}$ of deionized water was stirred for 24 hours in the dark at room temperature. The AgI precipitate was removed by filtration, and the filtrate was reacted with a freshly prepared solution of barium 3-carboxyboldinate (prepared from $0.240 \mathrm{~g}, 0.59 \mathrm{mmol}$ of 3-carboxyboldine with $0.115 \mathrm{~g}$, $0.60 \mathrm{mmol}$ of $\mathrm{Ba}(\mathrm{OH})_{2} \times \mathrm{H}_{2} \mathrm{O}$ in $5 \mathrm{~mL}$ of deionized water) for 24 hours at room temperature. The precipitate was filtered, washed with deionized water $(2 \times 3 \mathrm{~mL})$, and dried. Yield: $0.186 \mathrm{~g}$ ( $0.27 \mathrm{mmol}, 46 \%$ based on Pt complex). ${ }^{1} \mathrm{H}$ NMR $\left(400 \mathrm{MHz}, \mathrm{DMSO}_{-} \mathrm{d}_{6}, 25^{\circ} \mathrm{C}\right) \delta 0.98$ (br s, $\left.2 \mathrm{H}, \mathrm{H}-\chi\right), 1.23$ (br s, 2H, H- $\beta$ ), 1.44 (br s, $2 \mathrm{H}, \mathrm{H}-\chi$ ), 1.90 (br s, $2 \mathrm{H}, \mathrm{H}-\beta$ ), 2.10$2.25(2 \mathrm{H}, \mathrm{m}, \mathrm{H}-5+\mathrm{H}-7), 2.33\left(3 \mathrm{H}, \mathrm{s}, \mathrm{N}-\mathrm{CH}_{3}\right), 2.68(1 \mathrm{H}, \mathrm{d}, \mathrm{J}=$ 14.2 Hz, H-6a), 2.80-2.95 (2H, m, H-5 + H-7), 3.60 (3H, s, 1$\left.\mathrm{OCH}_{3}\right), 3.76\left(3 \mathrm{H}, \mathrm{s}, 10-\mathrm{OCH}_{3}\right), 6.68(1 \mathrm{H}, \mathrm{s}, \mathrm{H}-8), 7.84(1 \mathrm{H}$, s, H-11), $9.12(1 \mathrm{H}, \mathrm{s}, \mathrm{OH}) .{ }^{13} \mathrm{C}$ NMR $\left(100 \mathrm{MHz}, \mathrm{DMSO}-\mathrm{d}_{6}\right.$, $\left.25^{\circ} \mathrm{C}\right) \delta 24.2(\mathrm{C}-\chi), 29.3(\mathrm{C}-4), 31.6(\mathrm{C}-\beta), 34.0(\mathrm{C}-7), 44.1(\mathrm{~N}-$ $\left.\mathrm{CH}_{3}\right), 53.3(\mathrm{C}-5), 55.8\left(10-\mathrm{OCH}_{3}\right), 58.6\left(1-\mathrm{OCH}_{3}\right), 63.6(\mathrm{C}-$ 6a), 112.8 (C-11), 114.8 (C-8), 116.6 (C-3), 122.8, 122.9, 127.5 (C1a), 130.4, 130.9, 142.8 (C-1), 145.8, 146.0 (C-10), 156.3, 172.9 (COO). IR (KBr disk) $3447 v(\mathrm{O}-\mathrm{H}), 3238 v(\mathrm{~N}-\mathrm{H}), 2934,1607$ 
$v(\mathrm{C}=\mathrm{O}), 1569,1507 \mathrm{~cm}^{-1}$. ESI-MS (positive mode) $\mathrm{m} / z 679$ $[\mathrm{MH}]^{+}$. Anal. Calc. for $\mathrm{C}_{26} \mathrm{H}_{33} \mathrm{~N}_{3} \mathrm{O}_{6} \mathrm{Pt}$ : C, 46.02; H, 4.90; N, 6.19. Found: C, 46.55; H, 4.70; N, 6.05 .

2.4. DPPH Assay. The DPPH assay was performed using a previously described method $[26,27]$. $0.1 \mathrm{~mL}$ of compounds L1, L5, L6, 1, and 2 (from 0.20 to $10 \mathrm{mM}$ solutions in ethanol) were mixed with $2.9 \mathrm{~mL}$ of a freshly prepared solution of $\mathrm{DPPH}^{*}$ (2,2-diphenyl-1-picrylhydrazyl) in ethanol $(50 \mu \mathrm{M})$. A solution obtained by mixing $2.9 \mathrm{~mL}$ of the $\mathrm{DPPH}^{\circ}$ solution with $0.1 \mathrm{~mL}$ of ethanol was used as the control. The absorbance of the resulting solutions, control, and blank (reagents only) was recorded after $15 \mathrm{~min}$ at room temperature. Each sample was replicated three times. The disappearance of $\mathrm{DPPH}^{\bullet}$ was detected spectrophotometrically at $517 \mathrm{~nm}$. The percent radical scavenging capacity (RSC) was calculated according to the following equation:

$$
\operatorname{RSC}(\%)=100 \% \times \frac{\left(A_{\text {control }}-A_{\text {sample }}\right)}{A_{\text {control }}} .
$$

From the obtained $\mathrm{RSC}(\%)$ values, the $\mathrm{IC}_{50}$ value, which represents the concentration of compounds that results in $50 \%$ neutralization, was determined by linear regression analysis.

2.5. FRAP (Ferric Reducing Antioxidant Power) Assay. The ferric reducing power of compounds L1, L5, L6, 1, and 2 was measured according to a previously published protocol with modifications [28]. This method is based on the reduction of a colorless ferric complex $\left(\mathrm{Fe}^{3+}\right.$-tripyridyltriazine) at a low $\mathrm{pH}$ to a blue-colored ferrous complex ( $\mathrm{Fe}^{2+}$-tripyridyltriazine) due to electron-donating antioxidants. The reduction was monitored by measuring the change in the absorbance at $593 \mathrm{~nm}$. The working FRAP reagent was prepared daily by mixing 10 volumes of a $300 \mathrm{mM}$ acetate buffer at $\mathrm{pH}$ 3.6 with 1 volume of $10 \mathrm{mM}$ TPTZ (2,4,6-tri(2-pyridyl)-striazine) in $40 \mathrm{mM}$ hydrochloric acid and 1 volume of $20 \mathrm{mM}$ ferric chloride. A standard curve was prepared using various concentrations of Trolox. All of the solutions were prepared daily. $100 \mu \mathrm{L}$ of the sample solutions and $300 \mu \mathrm{L}$ of deionized water were added to $3 \mathrm{~mL}$ of the freshly prepared FRAP reagent. The reaction mixture was incubated for $30 \mathrm{~min}$ at $37^{\circ} \mathrm{C}$ in a water bath. Then, the absorbance of the samples was measured at $593 \mathrm{~nm}$. A sample blank reading using ethanol was also recorded. The difference between the sample absorbance and the blank absorbance was determined and used to calculate the FRAP value. In this assay, the reducing capacity of the tested compounds was calculated in reference to the reaction signal given by a Trolox solution. The FRAP values are expressed as mM Trolox. All of the measurements were performed in triplicate.

2.6. In Vitro Inhibition Growth Assay. The experimental cell cultures were obtained from the American Type Culture Collection (Rockville, MD, USA). The HT-29 colon cancer cell line, MCF-7 breast adenocarcinoma cell line, and CCD841 (CoN) human colon epithelial cell line were grown in Dulbecco's modified Eagle's medium (DMEM) containing
$10 \% \mathrm{FCS}, 100 \mathrm{U} / \mathrm{mL}$ penicillin, $100 \mu \mathrm{g} / \mathrm{mL}$ streptomycin, and $1 \mathrm{mM}$ glutamine. The cells were seeded into 96 -well microtiter plates in $100 \mu \mathrm{L}$ volumes at a plating density of $5 \times 10^{3}$ cells/well. After $24 \mathrm{~h}$ of incubation at $37^{\circ} \mathrm{C}$ under a humidified $5 \% \mathrm{CO}_{2}$ atmosphere to allow for cell attachment, the cells were treated with different concentrations of the drugs (L5, L6, 1, 2, and oxaliplatin) and incubated for $72 \mathrm{~h}$ under the same conditions. The sulforhodamine B assay was used to evaluate cell viability according to the method reported by Skehan et al. [29, 30]. Next, the cells were fixed with $50 \%$ trichloroacetic acid at $4^{\circ} \mathrm{C}$. After washing with water, the cells were stained with $0.1 \%$ sulforhodamine B (SigmaAldrich, St. Louis, MO, USA), dissolved in $1 \%$ acetic acid (50 $\mu \mathrm{L} /$ well) for $30 \mathrm{~min}$ and subsequently washed with $1 \%$ acetic acid to remove any unbound stain. The proteinbound stain was solubilized with $100 \mu \mathrm{L}$ of $10 \mathrm{mM}$ unbuffered Tris base, and the cell density was determined using a spectrophotometric plate reader (wavelength $540 \mathrm{~nm}$ ). The values are reported as the means \pm SD of three independent experiments. The GraphPad software (GraphPad Software, San Diego, CA, USA) was used to calculate the $\mathrm{IC}_{50}$ values. For the preadministration of 3-carboxyboldine ( $\mathrm{L} 5 \cdot \mathrm{HCl})$ or 3-carboxypredicentrine $(\mathrm{L} 6 \cdot \mathrm{HCl})$, the cells were previously pretreated for $24 \mathrm{~h}$ prior to oxaliplatin addition. The stock solutions of the compounds were prepared in DMSO, and the final concentration of this solvent was maintained at $0.1 \%$. The control cultures were only treated with $0.1 \%$ DMSO.

2.7. Statistical Analysis. The data in Sections 2.4 and 2.5 were reported as mean values \pm standard deviation (SD). After tests of normality and homoscedasticity (Kolmogorov-Smirnov and Cochran tests, resp.), Kruskal-Wallis ANOVA was used with a confidence level of $95 \%$. The values that represent the concentrations of investigated compounds that cause $50 \%$ inhibition $\left(\mathrm{IC}_{50}\right)$ were determined by linear regression analysis of the radical scavenging capacity (\% RSC). A similar procedure was performed for the FRAP assays (STATISTICA 7.0 program).

\section{Results and Discussion}

3.1. Synthesis of 3-Carboxyboldine ( $\mathrm{L} 5 \cdot \mathrm{HCl})$. 3-Carboxyboldine was obtained employing the lithium-bromide exchange reaction strategy under the same experimental conditions reported for 3-carboxypredicentrine ( $\mathrm{L} 6 \cdot \mathrm{HCl})$ [19]. The lithiation precursor 2,9-dimethoxymethyl-3-bromoboldine (L3) was prepared as described in the literature [23]. However, the use of dry acetone instead of dry ethanol improved the methoxymethylation yield from 24 to $52 \%$. Scheme 1 summarizes the synthetic procedure performed where L5 was isolated as a chlorohydrate salt. However, better ${ }^{1} \mathrm{H}$ and ${ }^{13} \mathrm{C}$ NMR spectra were recorded for L5 in the free base form. The ${ }^{1} \mathrm{H}$ NMR spectra contain the signals associated with the three characteristic methyl groups at $\delta 2.64\left(\mathrm{~N}-\mathrm{CH}_{3}\right), 3.64(1-$ $\left.\mathrm{OCH}_{3}\right)$, and $3.77\left(10-\mathrm{OCH}_{3}\right)$ as well as the two aromatic protons at $\delta 6.72(\mathrm{H}-8)$ and $7.85(\mathrm{H}-11) \mathrm{ppm}$. The proton spectra also revealed one phenolic proton at $9.24 \mathrm{ppm}$ in $\mathrm{DMSO}-\mathrm{d}_{6}$ (and in $\mathrm{CD}_{3} \mathrm{OD}$ ) and no additional signals associated with 


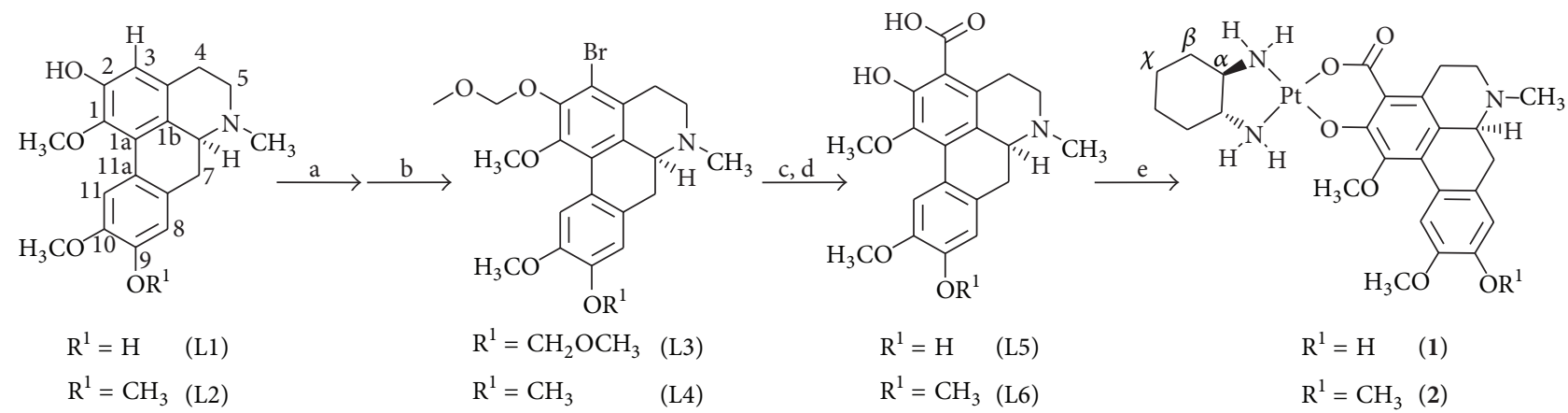

Scheme 1: General synthetic procedure for compounds L5, L6, 1 and 2. a: NBS (1.1 equiv), $\mathrm{CF}_{3} \mathrm{COOH}$, room temperature, 2 h; b: $\mathrm{NaOH}$, $\mathrm{H}_{2} \mathrm{O}, \mathrm{CH}_{3} \mathrm{OCH}_{2} \mathrm{Cl}$, anhydrous acetone, anhydrous pyridine, room temperature, $2 \mathrm{~h}$; c: $\mathrm{n}$ - BuLi $1.6 \mathrm{M}$, anhydrous $\mathrm{THF},-78^{\circ} \mathrm{C} \rightarrow$ room temperature, $\mathrm{CO}_{2}\left(10 \mathrm{~min}\right.$.); d: $\mathrm{HCl} 2 \mathrm{M}$, i-PrOH, THF, room temperature, $16 \mathrm{~h}$; e: $\left[\mathrm{Pt}(\mathrm{dach})\left(\mathrm{OH}_{2}\right)_{2}\right]\left(\mathrm{NO}_{3}\right)_{2}$ or $\left[\mathrm{Pt}(\mathrm{dach})\left(\mathrm{OH}_{2}\right)\left(\mathrm{OSO}_{3}\right)\right], \mathrm{H}_{2} \mathrm{O}$, room temperature, $16 \mathrm{~h}$.

the second $\mathrm{OH}$ and $\mathrm{COOH}$ proton at lower fields. For the previously reported $\mathrm{L} 6 \cdot \mathrm{HCl}$, no signals associated with these functional groups were observed [19]. The ${ }^{13} \mathrm{C}$ NMR spectra of 3-carboxyboldine (L5) contained a signal at $172.0 \mathrm{ppm}$ (associated to $\mathrm{COOH}$ ) in addition to the characteristic signals of the natural precursor, and most of these signals were assigned by $2 \mathrm{D}-\mathrm{HSQC} / \mathrm{HMBC}$ experiments. The ESI mass spectrum (positive mode) contained the $\mathrm{m} / z 372[\mathrm{M}+\mathrm{H}-$ $\mathrm{Cl}]^{+}$fragments, and the negative mode spectrum revealed the $\mathrm{m} / z 370[\mathrm{M}-\mathrm{H}-\mathrm{Cl}]^{-}$fragment, confirming the presence of a compound with the general formula $\mathrm{C}_{20} \mathrm{H}_{21} \mathrm{NO}_{6}$ (molecular weight $371 \mathrm{~g} / \mathrm{mol}$ ). The characterization of compound L5 was also confirmed by reaction with freshly prepared $\mathrm{CH}_{2} \mathrm{~N}_{2}$ to form the methylated derivative. Thin layer chromatography analysis and the proton and carbon chemical shifts of the methylated derivative are in agreement with the signals of previously reported 3-carboxypredicentrine (L6).

3.2. Synthesis of [Pt(dach)(L5)] (1). An aqueous solution of $\left[\mathrm{Pt}(\mathrm{dach})\left(\mathrm{OH}_{2}\right)_{2}\right]\left(\mathrm{NO}_{3}\right)_{2}$ was obtained by reaction of [Pt(dach) $\mathrm{I}_{2}$ ] with 2 equivalents of $\mathrm{AgNO}_{3}$ for 24 hours in the absence of light. This solution was reacted with a freshly prepared barium 3-carboxyboldinate solution to yield 1 as a purple insoluble product in $46 \%$ yield. The ${ }^{1} \mathrm{H}$ NMR chemical shifts were compared with those previously reported for $[\mathrm{Pt}(\mathrm{dach})(\mathrm{L} 6)](2)$, and the expected differences were observed as follows: (a) an additional signal at $\delta$ $9.12(1 \mathrm{H}, \mathrm{s})$ associated with the phenol at position C-9 and (b) the disappearance of one signal at approximately $\delta 3.7\left(3 \mathrm{H}\right.$, s) associated with the $\mathrm{OCH}_{3}$ group at C-9 position. These results confirmed the coordination of 3carboxyboldine (see Supplementary Material available online at http://dx.doi.org/10.1155/2015/920143). The ${ }^{13}$ C NMR spectra show the carbonyl chemical shift at $\delta 172.9 \mathrm{ppm}$ (in agreement with $\delta 172.3$ for 2 ), and most of the signals were assigned by $2 \mathrm{D}-\mathrm{HSQC} / \mathrm{HMBC}$ experiments. The infrared spectrum showed the partial disappearance of the broad band from 2500 to $3500 \mathrm{~cm}^{-1}$ (including carboxylic acid and phenol $\mathrm{OH}$ stretching) along with a slight shift in the $\mathrm{CO}$ band from $1613 \mathrm{~cm}^{-1}$ in L5 to $1607 \mathrm{~cm}^{-1}$ in 1 . In addition, a new band at $3238 \mathrm{~cm}^{-1}$ associated with $\mathrm{N}-\mathrm{H}$ stretching in $\mathbf{1}$ was observed (see Supplementary Material). The ESI mass spectrum (positive mode) shows the parent ion at $m / z 679$ $\left(\mathrm{MH}^{+}\right)$, and the ions at $m / z 372$ and $\mathrm{m} / z 328$ are associated with the protonated form of 3-carboxyboldine and boldine, respectively.

3.3. DPPH Assay. The antioxidant activity of boldine (L1) and the 3-carboxyboldine $(\mathrm{L} 5 \cdot \mathrm{HCl}$ ) and 3-carboxypredicentrine $(\mathrm{L} 6 \cdot \mathrm{HCl})$ synthesized derivatives was investigated to compare the radical scavenger properties of the derivatives with the natural precursor. In addition, platinum(II) coordination compounds $\mathbf{1}$ and $\mathbf{2}$ were also tested to evaluate their antioxidant activity upon boldine derivative coordination. Table 1 shows the antioxidant activity (expressed as $\mathrm{IC}_{50}$ values) of these compounds in the DPPH assay. For comparison, Table 1 also includes the results for the commercial drug oxaliplatin and the commercial antioxidant Trolox.

Based on the results, 3-carboxyboldine (L5) exhibits a scavenging activity toward stable free radicals that is 18 times greater than that of 3-carboxypredicentrine (L6) and approximately half of the activity exhibited by the natural precursor boldine (L1). This result suggests that the introduction of the carboxy substituent at the C-3 position of boldine does not favor the $\mathrm{H} \cdot$ donor ability of the compounds. The presence of the phenol at position C-9 in 3-carboxyboldine (L5) contributes to its higher antioxidant activity. However, platinum coordinated compounds $\mathbf{1}$ and $\mathbf{2}$ exhibited a considerably higher radical scavenger behavior (130 and 13 times, resp.) than the commercial drug oxaliplatin and even better than the corresponding carboxy derivatives (i.e., L5 and L6). The $\mathrm{IC}_{50}$ values obtained for $\mathbf{1}$ and $\mathbf{2}$ in this chemical assay indicate that coordination of antioxidant compounds L5 and L6 to the $\mathrm{Pt}(\mathrm{dach})$ moiety substantially enhances the antioxidant behavior of the oxaliplatin analogues.

3.4. FRAP Assay. Figure 1 shows the antioxidant activity (expressed as Trolox equivalent activity capacity, TEAC) of synthesized compounds L5, L6, $\mathbf{1}$, and $\mathbf{2}$ at $1 \mathrm{mM}$ concentration in the FRAP assay compared to the natural precursor boldine (L1), the commercial drug oxaliplatin, and the commercial antioxidant BHT. 
TABLE 1: Antioxidant activity $\left(\mathrm{IC}_{50}\right)$ in DPPH assay.

\begin{tabular}{lc}
\hline Compound & $\mathrm{IC}_{50}(\mathrm{mM})$ \\
\hline L1 & $1.71 \pm 0.03$ \\
L5 & $3.20 \pm 0.10$ \\
L6 & $58 \pm 8$ \\
$\mathbf{1}$ & $2.68 \pm 0.08$ \\
$\mathbf{2}$ & $26 \pm 9$ \\
Oxaliplatin & $350 \pm 70$ \\
Trolox & $0.40 \pm 0.01$ \\
\hline
\end{tabular}

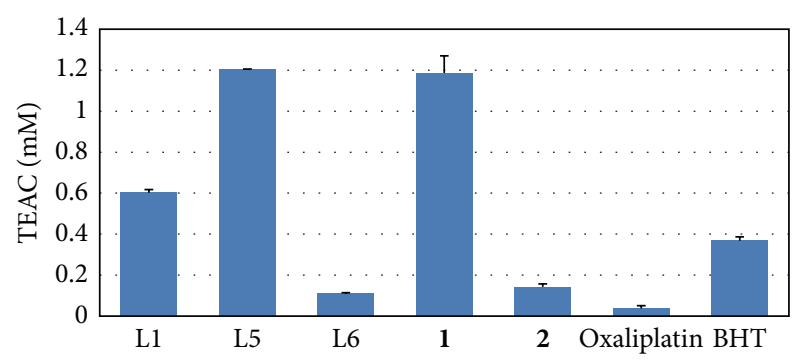

FIGURE 1: Antioxidant activity (Trolox equivalent activity capacity, TEAC) at $1 \mathrm{mM}$ concentration, in FRAP assay.

The results indicate that 3-carboxyboldine (L5) exhibits a reducing antioxidant power 11 times greater than that of 3 carboxypredicentrine (L6) and 2 times greater activity than that of the natural substrate boldine (L1). Platinum coordinated compound 1 exhibits an equivalent activity $(P>0.05)$ compared to 3-carboxyboldine (L5), which is approximately 30 times more than the reducing activity of the commercial drug oxaliplatin. However, 3-carboxypredicentrine (L6) exhibits a decreased reducing power compared to the natural product boldine (L1) and the commercial antioxidant BHT. Platinum coordination compound 2 exhibits approximately 4 times more reducing activity than oxaliplatin. The difference in activity between both of the carboxy derivatives of boldine (L5 and L6) and their platinum compounds (1 and 2) is in agreement with the results obtained in the DPPH assay. The greater reducing antioxidant power of 3-carboxyboldine (L5) may be due to the presence of the phenol at the C-9 position of the aporphinic skeleton.

3.5. In Vitro Inhibition Growth Assay. The inhibitory concentrations (expressed as $\mathrm{IC}_{50}$ ) of the carboxy derivatives of boldine ( $\mathrm{L} 5 \cdot \mathrm{HCl}$ and $\mathrm{L} 6 \cdot \mathrm{HCl})$, their corresponding platinum(II) coordination compounds (1 and 2 ), and oxaliplatin toward two human tumor cell lines (MCF-7 and HT-29) and one human nontumor cell line (CCD-841) are shown in Table 2 . No measurable cytotoxic activity $(>100 \mu \mathrm{M})$ against the studied cell lines was observed for L5 and L6, which is in agreement with the behavior of L6 toward the previously tested MDA-MB-231, PC-3, and DHF cell lines [19]. However, their platinum-derived compounds (1 and 2) exhibited a similar biological activity against the two human tumor cell lines studied and were slightly less cytotoxic (two to four times) against the human nontumor cell line (CCD-841) compared to oxaliplatin. These results revealed that naturally
TABLE 2: Inhibitory concentration ( $\mathrm{IC}_{50}$ ) of compounds L5, L6, 1, and 2 compared to oxaliplatin toward two human tumor cell lines (MCF-7 and HT-29) and one nontumor cell line (CCD-841).

\begin{tabular}{lccc}
\hline Compound & \multicolumn{3}{c}{$\mathrm{IC}_{50}(\mu \mathrm{M})$} \\
L5 & MCF-7 & HT-29 & CCD-841 \\
L6 & $>100$ & $>100$ & $>100$ \\
$\mathbf{1}$ & $>100$ & $>100$ & $>100$ \\
$\mathbf{2}$ & $2.8 \pm 0.5$ & $15.1 \pm 2.1$ & $11.3 \pm 0.4$ \\
Oxaliplatin & $4.1 \pm 0.4$ & $5.9 \pm 1.2$ & $19.1 \pm 2.0$ \\
\hline
\end{tabular}

derived oxaliplatin analogues $\mathbf{1}$ and 2 preserve the cytotoxicity featured by platinum-based compounds and the enhanced antioxidant properties of these compounds do not interfere with their cytotoxic activity.

To determine whether carboxy boldine derivatives L5 and L6 contribute to decreasing the cytotoxic activity of the platinum moiety especially in a human nontumor cell line, pretreatment assays were performed. The preadministration of $\mathrm{L} 5 \cdot \mathrm{HCl}$ or $\mathrm{L} 6 \cdot \mathrm{HCl}(50 \mu \mathrm{M})$ for $24 \mathrm{~h}$ in the colon tumor (HT-29) and colon nontumor (CCD-841) cell lines prior to the oxaliplatin $(50 \mu \mathrm{M})$ regimen significantly increased the cell viability to approximately $33 \%$ for the tumor cell line and approximately $85 \%$ for the nontumor cell line (Figure 2 ). The improved enhancement in cell survival that was observed in the nontumor cell line is a promising result, and the potential biological role exerted by L5 and L6 should be elucidated.

\section{Conclusions}

The synthesis of platinum-based compounds with recognized antioxidant compounds as ligands has not been sufficiently developed as a new approach for the design of a potentially new therapy with lesser secondary toxicities. In this study, we reported the synthesis and characterization of a new oxaliplatin analog $[\mathrm{Pt}(\mathrm{dach})(\mathrm{L} 5)]$ (1), where L5 = 3-carboxyboldine, as a continuation of the work on the previously reported $[\mathrm{Pt}(\mathrm{dach})(\mathrm{L} 6)](2)$, where L6 = 3carboxypredicentrine. L5 was prepared from the natural product boldine (L1) in 19\% overall yield in three steps. The antioxidant activity of the natural precursor (L1), synthesized compounds L5, L6, 1, and 2, and oxaliplatin was investigated using two chemical-based assays. The results indicated that compounds 1 and $\mathbf{2}$ exhibited an antioxidant behavior that was several times higher than oxaliplatin (130 and 13 times for 1 and 2 in DPPH assay and 30 and 4 times for 1 and 2 in FRAP assay). The difference in the antioxidant activity of synthesized platinum compounds $\mathbf{1}$ and $\mathbf{2}$ correlated well with the enhanced antioxidant activity of L5 compared to L6. The cytotoxic activity (expressed as $\mathrm{IC}_{50}$ ) of $\mathbf{1}$ and $\mathbf{2}$ was comparable to the commercial drug oxaliplatin toward the two human tumor cell lines studied and approximately two to four times lower for the human nontumor cell line. In addition, carboxy derivatives L5 and L6 exhibited no measurable activity toward any of the studied cell lines. The pretreatment assay revealed a cytoprotective effect for L5 and 

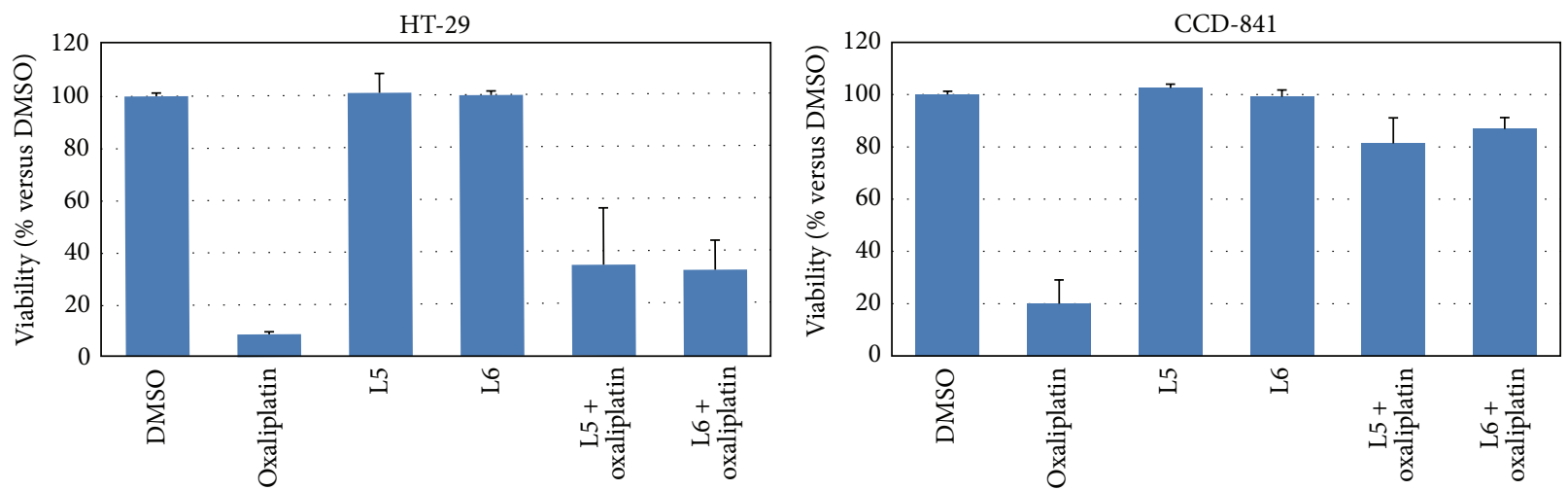

FIGURE 2: Viability of $24 \mathrm{~h}$ pretreated (with $50 \mu \mathrm{M}$ of L5 $\cdot \mathrm{HCl}$ or L6 $\cdot \mathrm{HCl}$ ) human tumor colon (HT-29) and human nontumor colon (CCD-841) cell lines prior to oxaliplatin administration $(50 \mu \mathrm{M})$.

L6 against oxaliplatin toxicity, especially on the nontumor cell line. This promising result will be confirmed in other tumor and nontumor cell lines and may promote the incorporation of natural compounds in chemotherapeutics regimes.

\section{Conflict of Interests}

The authors declare that there is no conflict of interests regarding the publication of this paper.

\section{Acknowledgments}

The authors wish to thank Fondecyt-CONICYT (Grant no. 11121254) and the Universidad de Valparaíso (DIUV 50/2011) for their financial support.

\section{References}

[1] S. Dasari and P. B. Tchounwou, "Cisplatin in cancer therapy: molecular mechanisms of action," European Journal of Pharmacology, vol. 740, pp. 364-378, 2014.

[2] L. Kelland, "The resurgence of platinum-based cancer chemotherapy," Nature Reviews Cancer, vol. 7, no. 8, pp. 573-584, 2007.

[3] B. W. Harper, A. M. Krause-Heuer, M. P. Grant, M. Manohar, K. B. Garbutcheon-Singh, and J. R. Aldrich-Wright, "Advances in platinum chemotherapeutics," Chemistry A: European Journal, vol. 16, no. 24, pp. 7064-7077, 2010.

[4] C.-H. Tang, C. Parham, E. Shocron, G. McMahon, and N. Patel, "Picoplatin overcomes resistance to cell toxicity in smallcell lung cancer cells previously treated with cisplatin and carboplatin," Cancer Chemotherapy and Pharmacology, vol. 67, no. 6, pp. 1389-1400, 2011.

[5] H. Kostrhunova, J. Kasparkova, D. Gibson, and V. Brabec, "Studies on cellular accumulation of satraplatin and its major metabolite JM118 and their interactions with glutathione," Molecular Pharmaceutics, vol. 7, no. 6, pp. 2093-2102, 2010.

[6] P. Saha, C. Descôteaux, K. Brasseur et al., "Synthesis, antiproliferative activity and estrogen receptor $\alpha$ affinity of novel estradiol-linked platinum(II) complex analogs to carboplatin and oxaliplatin. Potential vector complexes to target estrogendependent tissues," European Journal of Medicinal Chemistry, vol. 48, pp. 385-390, 2012.

[7] E. Gabano, M. Ravera, C. Cassino, S. Bonetti, G. Palmisano, and D. Osella, "Stepwise assembly of platinum-folic acid conjugates," Inorganica Chimica Acta, vol. 361, no. 5, pp. 1447-1455, 2008.

[8] R. A. Tromp, S. S. G. E. van Boom, C. M. Timmers et al., "The $\beta$-glucuronyl-based prodrug strategy allows for its application on $\beta$-glucuronyl-platinum conjugates," Bioorganic \& Medicinal Chemistry Letters, vol. 14, no. 16, pp. 4273-4276, 2004.

[9] Y.-P. Ho, K. K. W. To, S. C. F. Au-Yeung, X. Wang, G. Lin, and $\mathrm{X}$. Han, "Potential new antitumor agents from an innovative combination of demethylcantharidin, a modified traditional chinese medicine, with a platinum moiety," Journal of Medicinal Chemistry, vol. 44, no. 13, pp. 2065-2068, 2001.

[10] H. A. Wee, I. Khalaila, C. S. Allardyce, L. Juillerat-Jeanneret, and P. J. Dyson, "Rational design of platinum(IV) compounds to overcome glutathione-S-transferase mediated drug resistance," Journal of the American Chemical Society, vol. 127, no. 5, pp. 1382-1383, 2005.

[11] H. S. Oberoi, N. V. Nukolova, A. V. Kabanov, and T. K. Bronich, "Nanocarriers for delivery of platinum anticancer drugs," Advanced Drug Delivery Reviews, vol. 65, no. 13-14, pp. 1667-1685, 2013.

[12] F. H. Sarkar and Y. Li, "Using chemopreventive agents to enhance the efficacy of cancer therapy," Cancer Research, vol. 66, no. 7, pp. 3347-3350, 2006.

[13] V. A. Carozzi, P. Marmiroli, and G. Cavaletti, "The role of oxidative stress and anti-oxidant treatment in platinuminduced peripheral neurotoxicity," Current Cancer Drug Targets, vol. 10, no. 7, pp. 670-682, 2010.

[14] M. U. Nessa, P. Beale, C. Chan, J. Q. Yu, and F. Huq, "Synergism from combinations of cisplatin and oxaliplatin with quercetin and thymoquinone in human ovarian tumour models," Anticancer Research, vol. 31, no. 11, pp. 3789-3797, 2011.

[15] M. U. Nessa, P. Beale, C. Chan, J. Q. Yu, and F. Huq, "Studies on combination of platinum drugs cisplatin and oxaliplatin with phytochemicals anethole and curcumin in ovarian tumour models," Anticancer Research, vol. 32, no. 11, pp. 4843-4850, 2012.

[16] B. M. Kaminski, D. Steinhilber, J. M. Stein, and S. Ulrich, "Phytochemicals resveratrol and sulforaphane as potential agents 
for enhancing the anti-tumor activities of conventional cancer therapies," Current Pharmaceutical Biotechnology, vol. 13, no. 1, pp. 137-146, 2012.

[17] L. M. Mendonça, C. D. S. Machado, C. C. C. Teixeira, L. A. P. D. Freitas, M. D. L. P. Bianchi, and L. M. G. Antunes, "Curcumin reduces cisplatin-induced neurotoxicity in NGF-differentiated PC12 cells," Neuro Toxicology, vol. 34, no. 1, pp. 205-211, 2013.

[18] Y. Shimeda, Y. Hirotani, Y. Akimoto et al., "Protective effects of capsaicin against cisplatin-induced nephrotoxicity in rats," Biological \& Pharmaceutical Bulletin, vol. 28, no. 9, pp. 16351638, 2005.

[19] F. A. Thomet, P. Pinyol, J. Villena, and P. G. Reveco, "Towards a more selective analogue of oxaliplatin: synthesis of [Pt((1R,2R)diaminocyclohexane)(3-carboxypredicentrinato)]," Inorganica Chimica Acta, vol. 384, pp. 255-259, 2012.

[20] R. A. Delgado, A. Galdámez, J. Villena, P. G. Reveco, and F. A. Thomet, "Synthesis, characterization and in vitro biological evaluation of $\left[\mathrm{Ru}\left(\eta^{6}\right.\right.$-arene $\left.)(N, N) \mathrm{Cl}\right] \mathrm{PF}_{6}$ compounds using the natural products arenes methylisoeugenol and anethole," Journal of Organometallic Chemistry, 2014.

[21] P. O’Brien, C. Carrasco-Pozo, and H. Speisky, "Boldine and its antioxidant or health-promoting properties," ChemicoBiological Interactions, vol. 159, no. 1, pp. 1-17, 2006.

[22] J. Fernández, P. Lagos, P. Rivera, and E. Zamorano-Ponce, "Effect of boldo (Peumus boldus Molina) infusion on lipoperoxidation induced by cisplatin in mice liver," Phytotherapy Research, vol. 23, no. 7, pp. 1024-1027, 2009.

[23] P. G. Reveco, F. A. Thomet, M. Asencio, and M. E. Sanguinetti, "Novel methoxymethyl 3-bromoboldine derivatives with improved capabilities as precursors for organic synthesis," Synthetic Communications, vol. 37, no. 4-6, pp. 821-828, 2007.

[24] C. S. Marvel and P. K. Porter, "Monochloromethyl ether," in Organic Syntheses, Collective Volume, vol. 1, John Wiley \& Sons, New York, NY, USA, 2nd edition, 1941.

[25] A. R. Khokhar, S. Al-Baker, S. Shamsuddin, and Z. H. Siddik, "Chemical and biological studies on a series of novel (trans-(1R,2R)-, trans-(1S,2S)-, and cis-1,2diaminocyclohexane)platinum(IV) carboxylate complexes," Journal of Medicinal Chemistry, vol. 40, no. 1, pp. 112-116, 1997.

[26] W. Brand-Williams, M. E. Cuvelier, and C. Berset, "Use of a free radical method to evaluate antioxidant activity," LWT-Food Science and Technology, vol. 28, no. 1, pp. 25-30, 1995.

[27] N. S. Lakić, N. M. Mimica-Dukić, J. M. Isak, and B. N. Božin, "Antioxidant properties of Galium verum L. (Rubiaceae) extracts," Central European Journal of Biology, vol. 5, no. 3, pp. 331-337, 2010.

[28] S. Dudonné, X. Vitrac, P. Coutiére, M. Woillez, and J.-M. Mérillon, "Comparative study of antioxidant properties and total phenolic content of 30 plant extracts of industrial interest using DPPH, ABTS, FRAP, SOD, and ORAC assays," Journal of Agricultural and Food Chemistry, vol. 57, no. 5, pp. 1768-1774, 2009.

[29] P. Skehan, R. Storeng, D. Scudiero et al., "New colorimetric cytotoxicity assay for anticancer-drug screening," Journal of the National Cancer Institute, vol. 82, no. 13, pp. 1107-1112, 1990.

[30] V. Vichai and K. Kirtikara, "Sulforhodamine B colorimetric assay for cytotoxicity screening," Nature Protocols, vol. 1, no. 3, pp. 1112-1116, 2006. 

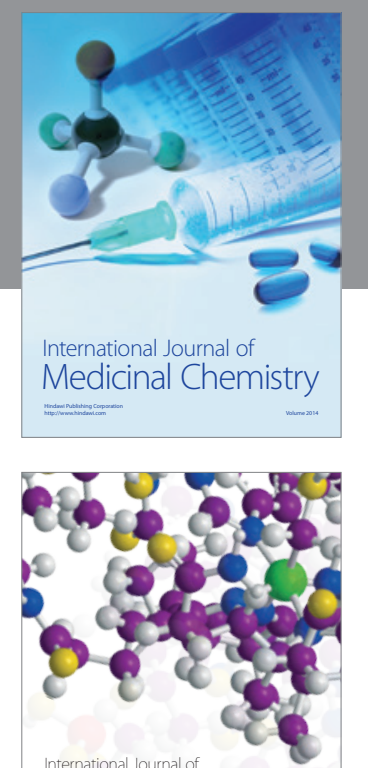

\section{Carbohydrate} Chemistry

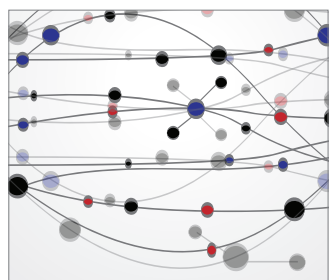

The Scientific World Journal
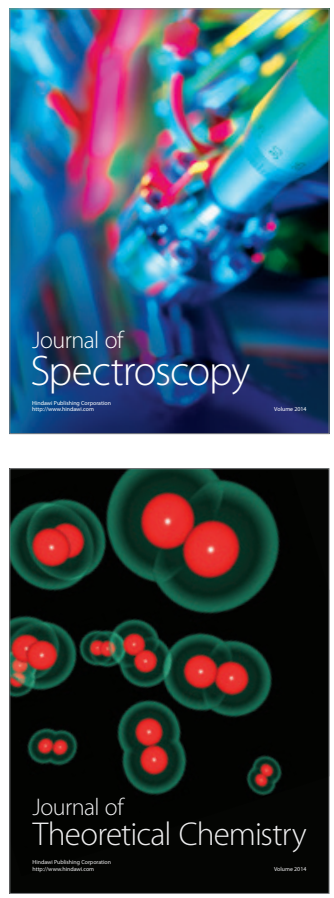
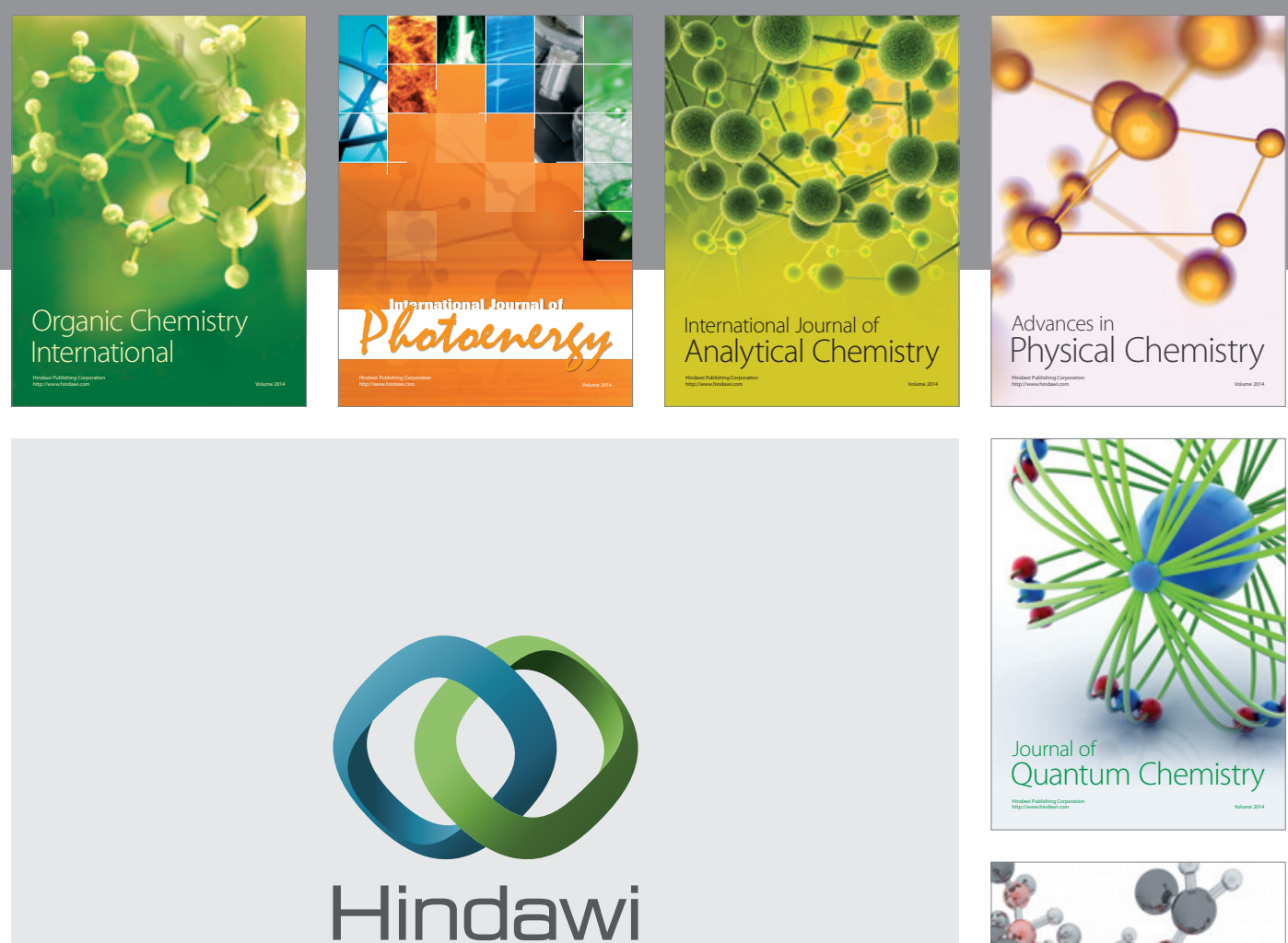

Submit your manuscripts at

http://www.hindawi.com

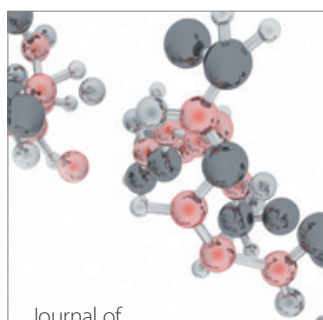

Analytical Methods

in Chemistry

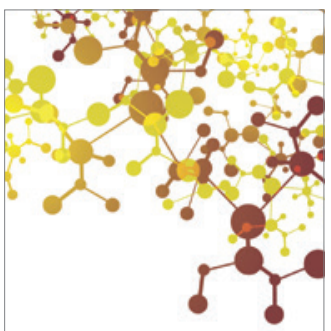

Journal of

Applied Chemistry

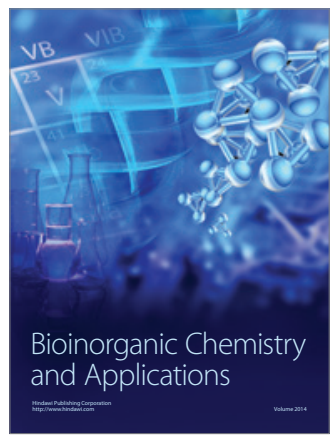

Inorganic Chemistry
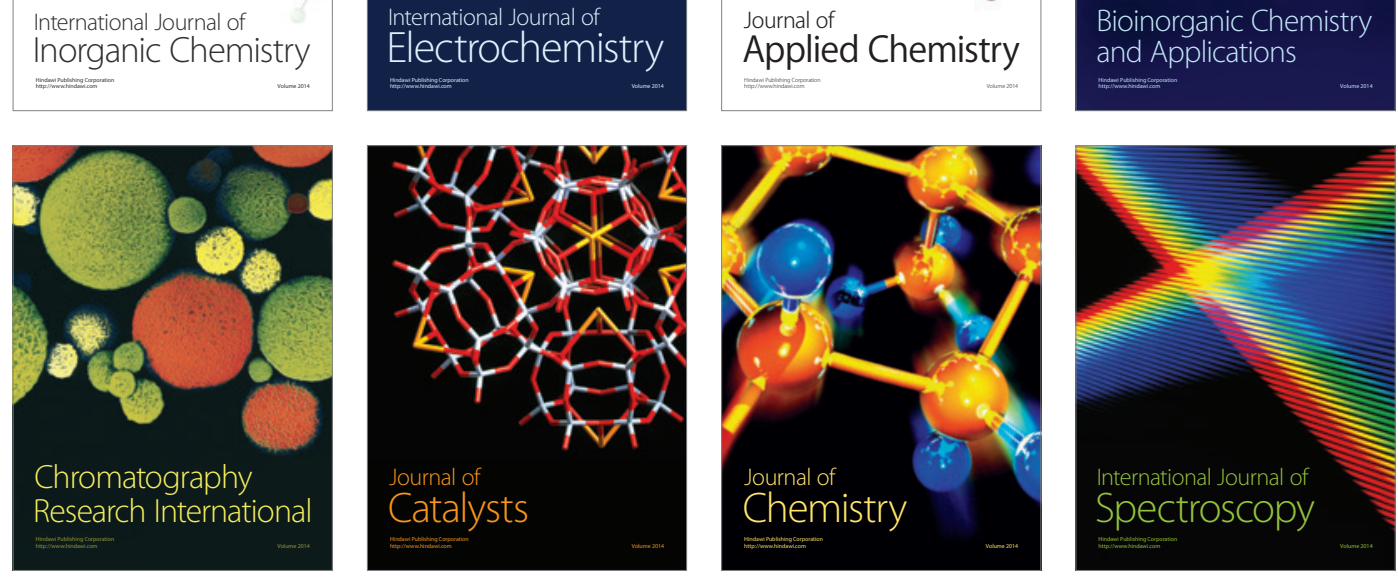